Perspectives on the standards agenda: exploring the agenda's impact on primary teachers' professional identities

Dr Zeta Brown and Prof Ken Manktelow

Wolverhampton University, Wulfruna Street, Wolverhampton, WV1 1LY

01384321000

zeta.brown@wlv.ac.uk

$\underline{\text { K.I.Manktelow@wlv.ac.uk }}$

Dr Zeta Brown is a lecturer in Childhood, Family and Community Studies at Wolverhampton University. She is also an executive member of the British Education Studies Association and the International Society for the Scientific Study of Subjectivity (the society that uses Qmethodology). Zeta's area of specialism is considering agendas such as standards and inclusion in primary education, particularly considering teachers' perspectives on the agenda's practical implementation.

Prof Ken Manktelow is Emeritus Professor of Psychology at the University of Wolverhampton. His main speciality is in thinking and reasoning, and he has also researched into human-computer interaction and developmental psycholinguistics. 


\title{
Perspectives on the standards agenda: exploring the agenda's impact on primary teachers' professional identities
}

\begin{abstract}
This study aimed to investigate teachers' perspectives on the practical implementation of the standards agenda and its impact on their professional identities. Q-methodology was used alongside semi-structured interviews with UK primary school teachers. The study explored the views of 25 teachers in 6 schools, selected through purposive sampling to give a range of individual and institutional demographics. Teachers in this research commented on the impact the standards agenda has had on parental and societal judgements that affect their identity as professionals. Teachers held differing positions on whether they experienced constraint or flexibility when implementing standards objectives. These differing positions were mainly influenced by whether they taught above or below Year 3. Teachers who found flexibility in the agenda's objectives had less occupational stress and increased ownership of their own actions and the standards agenda. Teachers' positions were complex and changed according to situational influences at a classroom level.
\end{abstract}

Keywords- standards agenda, teachers, primary, education.

Significant changes in the education system have occurred since the introduction of the Education Act (1980) and the Education Reform Act (1988). These acts signalled the first phase of a new competitive ethos amongst schools, promoting a market-led change in the education system (Galloway and Edwards, 1991). There became greater centralised control of the curriculum and assessment, reducing teachers' responsibility for designing the curriculum and using their own professional judgement with regard to standards (Gunter, 2008). Research on teachers' professional identities found that the standards agenda has greatly impacted on the profession. Carlgren (1999) states teachers were de-professionalised by these changes, their practical knowledge no longer seen as enough to grant them professional status. Teachers are now required to earn their professional status by adhering to the standards agenda. The paper initially examines an historical account on society's views of teachers and perceived identities. This leads into detailing the introduction of the standards agenda, the impact the agenda has had on schools and the implementation of standards in today's education system. The second part of the paper focuses on a study that 
investigated teachers' perspectives on the practical implementation of the standards agenda and its impact on their professional identities.

\section{An historical outlook on society's views of teachers and their perceived professional identity}

Teacher professionalism can be seen as a social construction, wherein the perceptions of teachers as professionals have changed according to the societal needs of the era (Webb et al., 2004). Therefore, teachers as a profession have experienced historically competing perspectives, which is the most contested issue in teaching to date (Beijaard et al., 2000). Throughout history the term 'professional' has described teachers as 'emblematic figures': as Stronach and his colleagues $(2002,111)$ state they are 'reduced to a singular meaning... and simultaneously inflated to improbable symbolic importance'. This brings about a sense of a 'harassed' profession, where teachers appear to have to change their identity as a teacher regularly to accommodate fluctuating societal positions on their profession.

Understandably, this has meant that teachers have had to continually reinvent their identity and roles. Hargreaves' (2000) research considers the historical development of teacher professionalism and observes that teachers have not always been seen as professionals. It was not until the 1960s that teachers achieved the pinnacle of high socially accepted professional status. The 'collegial teacher' at this time saw the diversity of the children in their class extended. Children from a greater mix of cultures and abilities were being integrated into co-educational mainstream schools. The 'collegial' age saw teachers having equal power and authority to determine the educational needs of the class. With increased responsibility came a greater societal trust in teachers; their knowledge and expertise were respected and they were granted a high public status (Hargreaves, 1994).

With the onset of marketisation in the 1980s, and the competition to improve on externally set educational standards, the teacher's role rapidly changed to require conformity to strict government guidelines. Left without the autonomy they once knew, teachers were held accountable for their actions by a public managerial system - the general public (Clarke and Newman 1997). Consequently, Stronach and his colleagues $(2002,115)$ state 'the political conflict relocates the centre of debate outside the profession itself, leaving the professionals 
mere spectators'. A competitive ethos emerged between schools and teachers and the profession became fragmented. Teachers were henceforth de-professionalised, their practical knowledge no longer seen as enough to grant them professional status (Carlgren, 1999). Ball $(1999,8)$ describes how:

...the combination of market and performative reforms bites deep into the practice of teaching and into the teachers' soul - into the 'classroom life' and world of imagination (Egan, 1994) ... the teacher-specific and diverse aspects of conduct are reworked and the locus of control over the selection of pedagogies and curricula is shifted.

A new 'commercialised' teacher professionalism emerged where teachers were granted professional status if they achieved the standardised set criteria and contributed to the schools' accountable achievements (Brennan, 1996; Webb et al., 2004). Teachers were now required to earn their professional status by adhering to the standards agenda.

Professionalism became intrinsically linked to a performance model of delivering vocational knowledge (Sachs, 2001). Poulson (1998) states that most people believe in the need for educational accountability. However Day's (2002) findings indicate that this seems to lower teachers' capabilities to teach, in order to focus on pre-determined standards. The introduction of the standards agenda could be said to have changed teachers into technicians, in a socially embedded discourse that has not changed in two decades (Adams and Tulasiewicz, 1995).

\section{The emerging standards agenda}

The standards agenda, present since 1980, irreversibly changed the education system into a market-oriented, public-facing system. Between 1969 and 1977 a series of Black Papers were written decrying a decline in educational standards. These Black Papers advocated the 'restoration of traditional teaching, traditional standards, traditional methods of streaming and selection, and traditional schools' (Carr and Harnett, 1996, 106). At this time, the Labour party had developed a socialist consensus encouraging Local Education Authorities (LEAs), schools and teachers to work together with the same goal: to provide a good education (Gray, 
2006). However, from the mid 1970s, there was an economic recession which saw high inflation and low economic growth undermine that socialist consensus.

The influence of trade unions was growing and there was an influx of strong criticisms from leading industrialists and employers who blamed the Labour party for a lack of skilled employees in the workforce (Chitty, 1989). The economic downturn made it difficult to continue along the path of social welfare: many saw weakness within the socialist manifesto and sought an alternative approach (Kavanagh, 1987). In light of these strong criticisms James Callaghan, Labour Prime Minister from 1976 to 1979, famously gave his Ruskin speech that emphasised the need for teacher accountability and central control of the curriculum. In this speech fears of underperformance were voiced that underpinned the introduction of the Education Reform Act by the succeeding government in 1988. Teachers were also targeted and an emphasis was placed on ensuring that the public knew of their actions; an ideological belief was introduced that determined a need to move towards a market-based approach.

The Conservative party was keen to replace socialism with a clear right-wing approach and a political discourse that encompassed the traditional social values of the party, whilst moving beyond the post-war consensus (Kavanagh, 1987; Quicke, 1988). The aim, as Sir Keith Joseph stated in 1975, was to reverse Labour's left-wing ratchet (Salter and Tapper, 1988). During the next election in 1979 the Conservative party heavily loaded its campaign on the failure of education (Batterson, 1999). A language of crisis emerged within the campaign whereby the general public was urged to believe that something had to be done with the education system (Quicke, 1988). The Conservatives used slogans such as 'Educashun Isnt Wurking' to highlight a breakdown in the education system and the rest of society which could only be rescued by the use of a robust interventionist approach. The Conservative party won this election and there was henceforth a move away from developing people towards improving performance. Chitty $(1989,14)$ states that the 'external economic circumstances connected with internal bureaucratic dynamic...[inspired]...a widespread belief that education should be geared more closely to the economy'. Thus, Margaret Thatcher wanted to increase the power of the 'consumer' and reduce the power held by the 'producers' (Whitty, 2008).

\section{The standards objectives that changed primary education}


The focus on changing the relationship between the government and schools continued in the Education Act (1980). LEAs had enjoyed partnership with both government and schools; in turn they held responsibility for many locally driven decisions. However, the Education Act (1980) decentralised power away from LEAs and centralised control whilst enhancing the parents' role. For the first time LEAs had to acknowledge parental choice, and schools were henceforth on a 'level playing field', where they had to appeal to parents (Galloway and Edwards, 1991). This Act signalled the first phase of a new competitive ethos amongst schools, promoting a market-led change in the education system.

However, while parents had more choice, the Conservatives redesigned the education system to enable greater centralised control. The publication 'Better Schools' (1985) emphasised a need for teachers to be held accountable for their performance and for the government to have more control of the curriculum on a national scale (DES, 1985). Ball (2008) states that this paper disempowered teachers by removing their ability to make important decisions in their curricula; in fact, both the curriculum decision-making and assessment processes were centralised. Teachers' unions were also displaced in the process and the government took over all standards objectives.

The Education Reform Act (1988) consolidated these changes, further reducing teachers' responsibility for designing the curriculum and using their own professional judgement with regard to standards (Gunter 2008). The newly developed National Curriculum linked curriculum breadth to traditional subjects in primary schools. Nine prescribed subjects were identified and teachers were provided with guidelines on what content to teach and how to teach it (Harnett and Vinney, 2008). The subsequent assessment framework was developed by the Task Group on Assessment Testing (TGAT) and was initially based exclusively on teacher assessment. However, in 1991, the Parents' Charter was introduced, giving parents the right to information about their local schools based upon their performance. The basis of parental knowledge was twofold, through use of a public assessment process and also inspections of individual schools. Summative assessment results at the end of each key stage, named Statutory Assessment Tests (SATs), were used to develop a national form of assessment. For primary schools this meant English, Maths and, initially, Science tasks (subsequently changed to teacher assessment for Science) in Key Stage One, and SATs in English, Maths and Science in Key Stage Two. 
In 1992, these results became publicly available in national league tables, where schools were ranked according to the proportion of children who achieved the desired 'national average' (Higgs et al., 1998). The publication of the SAT results in league tables prioritised the SAT process as a high stakes test for schools, placing schools in direct competition with one another. The Education Act (1992) also instituted the Office for Standards in Education (Ofsted), a non-ministerial department. Following this Act, schools were subject to intermittent external assessment by this department to ensure that they were adhering to standards objectives (Brown et al., 2002; Gillard 2011). The Education Act (1992) envisaged 'improvement through inspection', with the use of inspection to enhance schools' public accountability for their actions (Chapman, 2002).

Over time the incoming New Labour government moderated its position on accountability and assessment, distancing itself from close identification with teacher unions (Pierson, 1998). As Labour evolved into New Labour, it developed a new stance based on the notion of a strong society of individuals who had a duty to each other in order for the economy to succeed. In the run up to the 1997 general election, New Labour had prioritised education in its manifesto, with Tony Blair publicly declaring a focus on 'education, education, education'; his aim was to 'modernise' the education system while keeping the focus on standards and assessment. New Labour embraced the need for educational marketisation as society's best route to prosperity and acknowledged the need to control the work undertaken by teachers. It appeared, according to Strain and Simkins (2008), that the change in government had increased standards conformity. The New Labour government developed the National Curriculum so that it became even more prescriptive. This was especially the case when the Literacy and Numeracy Strategies of 1998 and 1999 changed the curriculum timetable, focusing half of all teaching time on literacy and numeracy (DfES 1998, 1999). This government also established the Early Years Foundation Stage (EYFS) in 2008, providing a National Curriculum for the early years. The party's sights were set firmly on schools being accountable through the national league tables, and schools were left to focus further on summative assessment, such as SATs.

\section{Today's implementation of the standards agenda}

The Coalition government, formed by a Conservative and Liberal Democrat collaboration following the election in 2010, inherited a very different economy to that of the buoyant New 
Labour years. However, the Coalition also developed education policy that focused on standards in schools. The Education Act (2011) claimed to help teachers raise standards, to improve underperformance in these standards and strengthen the ways teachers are held accountable for their actions. This Act concentrated on reforms for the development of new schools, with preference given to academies and free schools (Department for Education 2012). Ofsted inspections were also re-focused by this Act to concentrate on educational standards and, as such, strengthening school accountability. In 2011, a review of the National Curriculum was announced wherein an advisory committee considered replacing the current National Curriculum with one that supports international economic success. The subsequent revisions to the curriculum encouraged teachers to use the National Curriculum as an outline of core knowledge. Teachers are said to have autonomy to plan exciting, engaging lessons based on the National Curriculum outline (Department for Education, 2013).

Current research on teachers' positions primarily focuses on the constraints of standards objectives. Bowers (2004) found that his teachers felt they had little room to make their own decisions in any aspect of the standards objectives. When considering the SAT objectives teachers appear predominantly to feel forced to conform. They have to 'prep' their children, focusing them solely on academic achievement (Fielding et al., 1999; Wyse and Torrance, 2009). Additionally, West et al. (1994) stated that teachers found the SAT process to be time-consuming, with detrimental increases in their workload. Harnett (2008) found that a high percentage of primary teachers considered children's achievements to lie outside the curriculum. They found that teachers in their research were committed to providing a broad and balanced curriculum but also emphasised the need for children to be happy and to enjoy learning.

\section{The study's methodological design}

The study investigated 25 teachers' positions on the standards agenda in 6 mainstream primary schools in three different Local Authorities in the West Midlands. The study's sample included two schools in affluent locations, two in low socio-economic locations, one Catholic and one Church of England primary school. Teachers in the study also varied in the years they taught and the length of their teaching experience. This form of purposive sampling was not intended to produce a comparative study, but was directed at gaining a wide selection of possible mainstream primary schools and teachers. The intepretivist focus 
of the study was on the participants' positions, acknowledging that these positions and one's actions can alter over time and can be dependent on situational circumstances. Findings can then be compared and contrasted between different periods of time or between different places (Cohen et al., 2011).

The study centred on a Q-methodology design that can be used to investigate the complexity in different participants' positions on a given subject where differences of opinion are expected (Combes, et al., 2004). Q-methodology is a way of thinking about research that focuses on providing subjectivity to participants. This approach to research enables an exploration of shared meaning through consideration of the social context in which participants find themselves (Kitzinger, 1999). Q-methodology involves participants sorting a set of statements onto a distribution grid, shaped as a reversed pyramid. Participants sort these cards based on whether they agree or disagree with each statement. As such, participants are comparing and contrasting the statements - there is no right or wrong response in the card sort (Brown, 1991/1992).

In total teachers sorted 48 statements covering the standards agenda objectives alongside the ideological need to include all mainstream children in activities. These statements included, 'I believe that if all my class do not achieve the 'national average' they are failing in their education' and 'I feel that I am part of the process within implementation of this initiative and therefore I am responsible for its success'. To enhance the qualitative data at card sort, participants were asked to describe on a report sheet why they had placed statements in the most extreme distribution columns. The distribution data was then analysed qualitatively and also quantitatively using the PQ method, which is a computerised method of inputting data and producing factors (Eden, Donaldson and Walker, 2005). The factors in this study represent commonalities in participants' positions on the standards agenda objectives. Following the card sort analysis 8 semi-structured interviews were carried out that further considered the complex positions of these participants. The interviews started with participants considering which analysed factor best represented their position; the rest of the interviews were structured around their responses.

\section{Validity and ethical considerations}


Cohen and colleagues (2011) believe that qualitative researchers should describe validity in terms of how far their research is able to detail participants' positions. Considering qualitative research in its entirety, validity is improved in five different ways - with the use of a pilot study; self-description; peer debriefing; respondent validation and triangulation.

The British Education Research Association's (BERA) (2011) ethical guidelines indicate that researchers need to disclose all relevant information regarding their research, prior to it being conducted. This study ensured that participants signed a written consent form that detailed all relevant research information, prior to their participation in the research. Additionally, in order to ensure confidentiality, information was not disclosed that could readily identify the participants. To ensure anonymity the report of this study uses pseudonyms for each individual teacher.

\section{Findings}

\section{Consequences of parental empowerment: judgements on the teaching profession}

In interview, seven out of eight teachers commented on the standards agenda and how it has impacted on the way they are perceived as teachers from either a parental or a societal perspective. Three teachers who have significant experience in the teaching profession questioned the changes in parental judgement they have witnessed. For Claire, parents now judge a school's success on achievement in SATs and the subsequent league tables. Susan and Doreen indicated a change in the nature of parent-teacher communication, from discussing concerns to questioning teachers' judgement. For Doreen this change appeared to have occurred because of parental empowerment and a societal distrust in teachers' independent ability. Doreen stated 'I don't think they have [the] respect they used to have, I don't think they trust us to do our jobs, um and I think parents feel more and more empowered to challenge what we say and ask us to justify what we are doing'. Additionally, Doreen discussed her dissatisfaction, as a professional, with being questioned in this way. She said '...we are professionals, you wouldn't go to the dentist [and say], "I don't like the way you are doing that filling", you don't go to a solicitor and say "I don't like the way you are drawing up those deeds," but people think they can wander into the classroom and say "Well I don't like the way you are teaching division, or why are you doing that with my child..." without trusting that we have actually taught lots of children'. 
Claire explained that parents expected more from her, as a teacher, in areas which were previously seen as part of the parents' remit. For instance, she worked in the Nursery Year and was having to take more responsibility in areas such as toileting and teaching colours and shapes.

\section{Lack of faith: societal judgements on the teaching profession}

For four additional teachers the standards agenda's impact on their professional identities extended from parental judgement to societal judgement. These teachers were clearly distinguished by the fact that, instead of focusing solely on parents, their responses referred to 'people' or the 'public' generally. Greg said that the public can only see a narrow form of testing and they then measure a school according to league table results. This perspective suggested a general dissatisfaction with the lack of faith placed in the teaching profession. Nisha stated 'I don't think people recognise that you are constantly scrutinised and you're constantly observed, which you wouldn't get in any other profession'. She went on to say '... it is a shame that we can't be trusted, even though we have the degree and we have done, you know, done all the work, it's a shame'.

\section{Accountability and considering individualisation}

In total, in their Q-sort data 17 out of 25 teachers revealed a clear division between the government's and their own assessment of success. Teachers in this study disagreed with the ideological concept of the standards agenda and therefore did not believe in the core reasoning behind the implementation of all its objectives. They focus on their disapproval of how they are measured as successful teachers. Doreen explained why the standards agenda is seen as important, 'LAs, OfSTED, parents look at league tables as indications of success'. Additionally, Victoria said that league table results are seen as important and are solely for politicians. In turn, Mia regarded the league table as being '.. at the heart of what the government thinks makes a good school/teaching'. Accountability appeared to be at the forefront of these teachers' positions on league tables. Rita commented that '...it seems the mark of a 'good teacher' is achieving a high percentage of level 5 and level 4 pupils in SATs, so the school is high up in the league tables'. 
In total 17 teachers also believed that the SAT process was given more emphasis in the education system than any other aspect. For these teachers the SAT process produced inaccurate data on children's educational progress and insufficiently measured pupil, teacher and school achievement. Doreen said in her report that the dominance of SATs overshadowed all other success in schools: 'Go on any course, read any government view "the school is marvellous because ... level $5 \mathrm{~s}$ ". She went further to say that she believes it is a case of 'silk purses and sow's ears!' because she believes the government and society cannot make a good quality assessment of schools using bad quality tests. These teachers measured their own success in ways that lie outside the SAT process, seeing success in relation to how their children had developed during the year. In doing so, their approach to success was much more individualised and measured personal development, without any focus on the national level. Teachers emphasised the need for children to be happy and enjoy learning and they chose to highlight individual progress outside academic study. For instance, Rita stated that children can be 'gifted in other areas, for example art, dance, drama, music, PE, sport...' Lily concluded that 'a good teacher ensures a child received a holistic, well-rounded education that equips them to deal with life'.

\section{Establishing ownership and autonomy in one's actions}

In the Q-sort data 14 out of 25 teachers indicated that they felt the constraint of the standards agenda to the extent where there was no room for professional autonomy. These teachers were mainly teaching Year 3 upwards and had a range of experience. In these findings the need to conform that was experienced by the teachers had consequences for them professionally. They felt pressure and, in turn, occupational stress as a direct consequence of the standards agenda. It appears that these teachers see the standards agenda as an external entity which governs their teaching. They stated that they have to concentrate on ensuring that the majority of children are ready to achieve the government's desired 'national average'. Essentially, teachers who held this perspective felt they had little autonomy in their actions and believed that they had to prioritise the standards agenda objectives.

In contrast, 11 teachers acknowledged flexibility in the objectives and believed they were able to use their professional autonomy to decide the agenda's practical implementation. These teachers were mainly teaching up to Year 3 and varied widely in the number of years they had in the profession. They too disagreed with elements of the objectives, including 
their different measurement of success, and they felt pressure to meet these objectives effectively. However, they appeared to take ownership of the agenda, and believed they had a part to play in its implementation. It appeared that these teachers implemented the objectives alongside their own professional objectives and were therefore able to move beyond seeing standards as restrictive.

\section{Seeking autonomy in an ever changing environment}

The findings from the Q-methodology card-sort revealed contrasting positions on standards agenda objectives. The difference in these two perspectives may derive from the differing experiences teachers face in the early and later years of primary education. In fact the Qmethodology card-sort findings suggest this as teachers who taught below Year 3 mainly saw flexibility, where those teaching Year 3 and above found constraint. However, the interview findings indicate that teachers' positions are fluid and interchangeable.

Teachers in this study focussed on their current experiences to justify their perspectives on the standards agenda. The interviews were carried out in the academic year following the card-sort and teachers' positions had changed according to their current circumstances. Their positions on the practical implementation of the agenda appeared to diversify across these two perspectives according to specific variables in their teaching experiences.

In interview, two of the teachers had moved year group and this had a dramatic influence on their positions on the standards objectives. They had moved into years that carried out SATs, one from Year 4 to 6 and another from Year 3 to 2. Nisha described how teachers across the years feel pressure to develop children for Year 2 and 6 tests. She explained 'come Year 6 it's the tests, so those years get it'. Additionally, she described how she felt more pressure in Year 2 than Year 3, and Doreen referred to the conflict she now encounters having moved to Year 6:

It's been interesting going to Year 6 because obviously I have been involved in the Key Stage Two SATs, which I have been lucky not to be involved in for a few years which has been a godsend ... I tried not to make it all about the SATs all year but you have to expose the children to examples of the test and you have to tell them how they are going to be worded and you have to give 
them practice sessions because it is a completely alien way of doing things unless you have and so that's what's frustrating because that isn't the type of teacher I like to be.

The increased pressure experienced, especially in the latter years of primary education, was echoed by Claire who taught in Reception. Claire thought her perception of the standards agenda was different from that of others who taught in the later years of primary education. She experienced flexibility in the agenda 'because we are early years and we are more flexible in the early years, whereas you're more constrained up the school'.

For Diane her position on the standards agenda also changed according to her cohort of children. She said:

Yes, I think it depends on the cohort of children as well, because you asked me that last year with last year's cohort who were quite a bright cohort, whereas this year they are not so bright, so my opinion may be different because I have had to change and not restrict myself to thinking of that profile because a lot of them won't be scoring on there.

It appears that, for these teachers, their positions on the standards agenda are changeable, depending on their experiences of both cohort and year group in each academic year. Experiencing the increased pressure of the externalised SAT process in Years 2 and 6 appears to affect their focus and, in turn, their position on the standards agenda. Additionally, for those teachers who did not move to a different year group, there appeared to be a perception that other teachers could be experiencing more pressure in other years. This was the case for teachers such as Susan, who had consistently taught Year 5, and Doreen, who had moved to teach Year 6 and who held the most extreme views of the pressures and constraints present within the standards agenda. Susan disagreed with the standards agenda because '...you are, you are judged so much on results that children are achieving but it's achieving on a set of data, when there is so much else that goes on'. Doreen, when discussing the league tables against which she is measured, said 'I think league tables are lies, damn lies and statistics, they are a joke'. 
Interestingly, the development of these experiences appears to change the connections teachers make between professional identity and government objectives over time. For teachers who had minimal teaching experience, their positions on the agenda were intrinsically linked to the government's objectives and to their practical experience thus far (Rachel; Nisha; Louise). However, the three teachers who each had over 10-20 years' experience were able to consider government agendas separately from their professional identities, relying more on their vast practical experience (Greg; Claire; Diane). Claire stated 'we use it to fit our children and we don't do it by the book, we do what we know is best and we do what we know works'. Inevitably, Doreen and Susan, each with over two decades' experience, described in detail the positions they held that contrasted with the government's agendas. They held the strongest views of all the teachers, particularly on the standards agenda, and were the most torn between what they wanted to do and what they had to do. They also had a reflective way of describing their current educational situations in the context of times past. The fact that they had experienced teaching prior to the Education Reform Act 1988 appeared to be a significant factor in this conflict. Doreen said '...I felt before I had a lot more fun, um, I still believe although I couldn't prove it that my pupils made as good if not better progress, um, I think the standards constrain and narrow the curriculum'.

\section{Discussion}

\section{Externally driven teacher identities: the impact of parental and societal judgements}

Teachers in interview discussed their discontent with the way they are perceived as professionals. They discussed experiencing parental or societal judgements that left most teachers feeling that their ability as a teacher was being questioned and judged. For these teachers the impact of the externalised assessment process appears to have had lasting consequences in relation to their identities as professionals. An important objective of the standards agenda was to empower parents in their children's education (Galloway and Edwards, 1991). The development of national league tables was one innovation that was intended to enable and empower the general public and to provide transparency and an open view of which schools were succeeding and failing (Higgs et al., 1998). Their introduction does appear to have empowered the general public, including parents, but it has meant that, for these teachers, their professional judgement is now routinely questioned. These teachers highlight the pressure of being held externally accountable and the need to earn their 
professional status by achieving in the externalised assessment process. They highlighted the contribution of SATs and national league tables to parental and societal judgements of teachers and schools. While Adams and Tulasiewicz (1995) consider the introduction of the standards agenda to have changed teachers into technicians, in a socially embedded discourse that has not changed in two decades, it would appear that teachers in this study do consider their identity as a profession to be externally driven by the judgements of parents and the general public.

\section{Redefining accountability in the standards agenda}

Whitty (2008) considered that the standards agenda had developed a new 'public managerial state' in which teachers and schools were publicly accountable for their actions. In comparison, Webb and colleagues (2004) consider the teaching profession to have become 'commercialised' with teaching having an externally driven professional identity. According to Sachs (2001) teachers link their performance to their professional identity. The government's emphasis on professional accountability and the need to achieve in league tables was discussed by many teachers in their reports. As with Poulson (1998) and Brown et al., (2002), the focus was not on the process of using national tests, it was on the way in which these national tests are measured. Their main concern was how they are measured as teachers within the externally driven assessment process. The teachers in this research did not protest against the need for public accountability; they disagreed with the way it is implemented.

The majority of teachers in this study disagreed with the use of SATs and league tables focused on academic achievement. For these teachers, this concentration on children's attainment excluded consideration of the 'whole' child's achievement. Through the use of an externally driven assessment process, teachers in this research felt that standards objectives dominated their actions because the measurements they entailed were the basis on which they have been judged as teachers. The findings resonate with the work of Wyse and Torrance (2009) who considered that the SAT process generated narrow concepts of success for children. These narrow parameters of success, with their focus on pre-determined standards, appear to lower teachers' capabilities to teach (Day, 2002). As in Harnett's (2008) research, teachers emphasised the need for children to be happy and enjoy learning and, in line with Pollard et al. (1994), they chose to highlight individual progress outside academic study. 
Comparatively, teachers in this research concentrated on 'individualisation', acknowledging individual child success and considering the 'whole' child, instead of choosing to focus on collective achievement. These teachers measured their own success on the basis of progress made by their pupils as individuals, rather than basing it solely on academic achievement.

\section{The demand for autonomy and ownership of the standards agenda objectives}

Predominantly in research, teachers appear to feel forced to conform to the standards objectives and have to 'prep' their children, focusing solely on academic achievement (Fielding et al., 1999; Wyse and Torrance, 2009). Fourteen teachers in this study felt that the constraints of the standards agenda left no room for professional autonomy. They felt pressure to conform to the objectives and suffered occupational stress. This reflects previous research conducted by Bowers (2004) which also found teachers felt that they had little room to make their own decisions when implementing the standards objectives in practice.

Moreover, Quicke's (1988) research also directly linked the standards agenda with teachers' experience of increased occupational stress. This group of teachers mainly taught in Year 3 upwards, which may provide an explanation for their resistance as they teach the National Curriculum and in Key Stage Two students are preparing for SATs that are nationally recognised in the league tables (Higgs et al., 1998).

In contrast to previous research 11 teachers found flexibility in the objectives and were able to use their professional autonomy. Whilst they still felt pressure to succeed they appeared to take ownership of the objectives and were able to move beyond them to consider their own professional objectives. These teachers however mainly taught up to Year 3 and therefore mainly experienced the EYFS curriculum or the beginnings of the National Curriculum and the Key Stage One SATs (Harnett and Vinney, 2008). Interestingly, the teachers in this study who felt constrained sought autonomy and ownership in their actions. Those who found autonomy in the agenda's objectives had less occupational stress and increased ownership of their actions and the agenda's objectives. As such, teachers in this study found more consonance in their actions when they were able to make decisions and actively use their professional autonomy.

\section{The consequence of situational influences: complexity in teachers' positions on the} standards agenda 
It is understandable that teachers' positions on educational agendas can change, just as societal perceptions of teachers have changed over time (Webb et al., 2004). However, teachers' positions in this study were complex and directly related to situational influences that could change year on year. Day and colleagues (2006) state that teachers reflect on their past and current experiences, personally and socially in light of political, social and personal changing circumstances. Cooper and Olsen (1996) and Lasky (2005) also indicate in their research that human agency cannot be disconnected from an individual's current experiences, including educational reforms. Comparatively, data from the same teachers over two academic years enabled this research to represent the complexity in positions that changed according to year group, cohort and teaching experience variables.

Day et al., (2006) suggested that teachers' positions on their professional identities change across their teaching careers. Indeed teachers' positions in this study developed as they sought to find autonomy. For teachers in the early stages of their careers these positions were intrinsically connected to government legislation. However, with more time in post, these teachers relied more on their own practical experience. These findings suggest that the teachers held very complex perspectives, influenced by variables that produced everchanging developments in their positions.

\section{Conclusion of findings}

The findings of this study show that, for the teachers in this research, the standards agenda has influenced and continues to influence their professional identity significantly. Teachers in interview felt scrutinised and questioned and that there was a general lack of faith in their profession. Other professions were mentioned, including dentists and solicitors, as examples where judgements would not be made in the same way as for the teaching profession.

Teachers in this research discussed how they felt compelled to implement the objectives because this is how they earn their identity as professionals. They have therefore changed their own perceptions of their identities as teachers to accommodate social pressures of accountability. However, while they implement the standards agenda's objectives, the majority of these teachers measure their own successes differently to the government. Instead of focusing on SATs and league table results, many teachers stated that they measure 
their own successes in children's individualised progression, emphasising personal development that is outside academic study. Therefore, many disregarded their placement in the league tables, in favour of measuring individual success.

Teachers held different perspectives on whether they found constraint or flexibility when practically implementing the standards agenda's objectives. In this study these contrasting perspectives appeared to be mainly influenced by whether teachers taught above or below Year 3. Teachers sought autonomy in their actions; those who did not find autonomy in the standards agenda objectives appeared to suffer more occupational stress and did not feel part of the process. In contrast, teachers who found autonomy had less occupational stress and, in turn, also felt ownership of their own actions and the agenda's objectives. They seemed to achieve more consonance in their actions when they were able to make decisions and use their professional autonomy actively. This finding shows the impact that having autonomy over one's actions can have on teachers' professional identities, positions and practical implementation of this agenda.

Finally, this study found that teachers' positions are complex and change according to situational influences at a classroom level. These variables include year group, cohort and teaching experience variables. The findings suggest that teachers' positions are influenced by their present state and will change according to each academic year's experiences. Therefore, experiences at classroom level are likely to continue to significantly influence these teachers' positions on the standards agenda.

\section{References}

Adams, A. and Tulasiewicz, W. 1995, in Whitty, G. 2000. "Teacher professionalism in new times". Professional Development in Education. 26(2): 281-295. doi:

$10.1080 / 13674580000200121$.

Ball, S. 1999. "Global trends in educational reform and the struggle for the soul of the teacher!" Accessed March $15^{\text {th }} 2011$. http://www.leeds.ac.uk/educol/documents/00001212.htm. 
Ball, S. 2008. The educational debate. Bristol: The Policy Press.

Batterson, C. (1999) The changing politics of primary education. Education 3-13. - (-): 6165 .

Beijaard, D., Verloop, N. and Vermunt, J. 2000. “Teachers' perceptions of professional identity: an exploratory study from a personal knowledge perspective". Teaching and Teacher Education. 16(-):749-764. doi: 10.1016/S07942-051X(00)00023-8.

BERA. 2011. "Ethical Guidelines for Educational Research". Accessed August $4^{\text {th }} 2011$. http://www.bera.ac.uk/files/2011/08/BERA-Ethical-Guidelines-2011.pdf.

Bowers, T. 2004. "Stress, teaching and teacher health". Education 3-13, 32(3): 73-80. doi: 10.1080/03004270485200361.

Brennan, M. 1996, in Day, C. 2002. "School reform and transitions in teacher professionalism and identity”. International Journal of Educational Research. 37(-): 677692. doi: 10.1016/S0883-0355(03)00065-X.

Brown, M., Ralph, S. and Brember, I. 2002. "Change-linked work-related stress in British teachers". Research in Education, 67(1):1-12. doi: 10.7227/RIE.67.1.

Brown, S. 1991/1992. “A Q Methodological tutorial.” Accessed September $20^{\text {th }} 2009$. http://facstaff.uww.edu/cottlec/QArchive/Primer1.html

Carlgren, I. 1999. "Professionalism and teachers as designers". Journal of Curriculum Studies. 31(1): 43-56. doi: 10.1080/002202799183287.

Carr, W. and Hartnett, A. 1996. Education and the Struggle for Democracy. The politics of educational ideas. Buckingham: Open University Press. 
Chapman, C. 2002. 'Ofsted and School Improvement: teachers' perceptions of the inspection process in schools facing challenging circumstances". School leadership and Management. 22(3): 257-272. doi: 10.1080/1363243022000020390.

Chitty, C. 1989. Towards a New Education System. The Victory of the New Right. Sussex: Falmer Press.

Clarke, J. and Newman, J. 1997, in Barker, B. 2008. "School reform policy in England since 1988: relentless pursuit of the unattainable”. Journal of Education Policy. 23(6): 669-683. doi: $10.1080 / 02680930802212887$

Cohen, L., Manion, L., Morrison, K. and Bell, R. 2011. Research Methods in Education. (7 ${ }^{\text {th }}$ ed.). London: Routledge.

Combes, H., Hardy, G. and Buchan, L. 2004. "Using Q-methodology to Involve People with Intellectual Disability in Evaluating Person-Centred Planning”. Journal of Applied Research in Intellectual Disabilities, 17(-): 149-159. doi: 10.1111/j.1468-3148.2004.00191.x.

Cooper, K. and Olsen, M. 1996, in Day, C., Elliott, B and Kington, A. 2006. "The personal and professional selves of teachers: stable and unstable identities". British Educational Research Journal. 32(64): 601-616. doi: 10.1080/01411920600775316

Day, C. 2002. "School reforms and transitions in teacher professionalism and identity". International Journal of Educational Research. 37(8): 677-692. doi: 10.1016/S08830355(03)00065-X.

Day, C. Elliott, B. and Kington, A. 2006. "The personal and professional selves of teachers: stable and unstable identities". British Educational Research Journal. 32(64): 601-616. doi: 10.1080/01411920600775316.

Department for Education. 2012. "Education Bill Received Royal Assent". Accessed January $15^{\text {th }}$ 2013. http://www.education.gov.uk/inthenews/inthenews/a00200186/education-billreceives-royal-assent. 
Department for Education. 2013. The National Curriculum in England: a framework. document. Accessed January $15^{\text {th }} 2013$.

https://www.gov.uk/government/uploads/system/uploads/attachment_data/file/210969/NC_fr amework_document__FINAL.pdf.

DES. 1985. Education in England. Accessed September 25 ${ }^{\text {th }} 2009$

http://www.educationengland.org.uk/documents/des/betterschools.html.

DfES. 1998, 1999. in Harnett, P. and Vinney, M. 2008. Understanding Primary Education. Developing professional attributes, knowledge and skills. Oxon: Routledge.

Eden, S., Donaldson, A. and Walker, G. 2005. "Structuring subjectivities? Using Q methodology in human geography". Area. 37(4): 413-422. doi: 10.1111/j.14754762.2005.00641.x.

Egan, K. 1994 in Ball, S. 1999. "Global trends in educational reform and the struggle for the soul of the teacher!" Accessed March 15 2011. http://www.leeds.ac.uk/educol/documents/00001212.htm.

Fieldings, S., Daniels, H., Creese, A., Hey, V. and Leonard, D. 1999. "The (mis)use of SATs to examine gender and achievement at key stage 2". Curriculum Journal. 10(2): 169-187. doi: 10.1080/0958517990100202.

Galloway, D. and Edwards, A. 1991. Primary school teaching and educational psychology. London: Longman.

Gillard, D. 2011. "Education in England: a brief history.” Accessed March 10 2011. http://www.educationengland.org.uk/history/timeline.html.

Gray. S. 2006. Teachers under siege. Stoke-on-trent. Trentham.

Gunter, H. 2008. "Policy and Workforce Reform in England". Educational Management Administration and Leadership. 36(2): 253-270. doi: 10.1177/1741143207087776. 
Hargreaves, A. 1994, in Day, C., Elliott, B. and Kington, A. 2006. "The personal and professional selves of teachers: stable and unstable identities". British Educational Research Journal. 32(64): 601-616. doi: 10.1080/01411920600775316.

Hargreaves, A. 2000, in Day, C., Elliott, B. and Kington, A. 2006. "The personal and professional selves of teachers: stable and unstable identities". British Educational Research Journal. 32(64): 601-616. doi: 10.1080/01411920600775316.

Harnett, P. 2008. Understanding Primary Education. Developing professional attributes, knowledge and skills. Oxon: Routledge.

Harnett, P. and Vinney, M. 2008, in Harnett, P. Understanding Primary Education. Developing professional attributes, knowledge and skills. Oxon: Routledge.

Higgs, G., Bellin, W., Farrell, S. and White, S. 1998. "Educational Attainment and Social Disadvantage: Contextualizing School League Tables". Regional Studies. 31(8): 775-789. doi: 10.1080/00343409750129607.

Kavanagh, D. 1987. Thatcherism and British politics: the end of consensus? Oxford: Oxford University Press.

Kelchtermans, G. 2005. “Teachers' emotions in educational reforms: self-understanding, vulnerable commitment and micropolitical literacy". Teaching and Teacher Education. 21(8): 995-1006. doi:10.1016/j.tate.2005.06.009.

Kitzinger, C. 1999. "Researching subjectivity and diversity. Q-Methodology in Feminist Psychology”. Psychology of Women Quarterly, 23(-): 267-276. doi:0361-6843/99.

Kukkonen, M. 2005, in Beauchamp, C. and Thomas, L. 2009 "Understanding teacher identity: An overview of issues in the literature and implications for teacher education". 39(2): 175-189. Cambridge Journal of Education. doi: 10.1080/03057640902902252. 
Lasky, S. 2005. “A sociocultural approach to understanding teacher identity, agency and professional vulnerability in a context of secondary school reform". Teaching and Teacher Education. 21(8): 899-916. doi: 10.1016/j.tate.2005.06.003.

McNally, J., Blake, A. Corbin, B. and Gray, P. 2008. "Finding an identity and meeting a standard: connecting the conflicting in teacher induction". Journal of Education Policy. 23(3): 287-298. doi: 10.1080/02680930801987794.

Pierson, C. 1998. "The New Governance of Education: The Conservatives and Education 1988-1997”. Oxford Review of Education. 24(1): 131-142. doi: 10.1080/0305498980240110.

Pollard, A., Broadfoot, P., Croll, P., Osborn, M. and Abbott, D. 1994. in, Harnett, P. and Vinney, M. 2008. Understanding Primary Education. Developing professional attributes, knowledge and skills. Oxon: Routledge.

Poulson, L. 1998. “Accountability, teacher professionalism and education reform in England”. Teacher Development. 2(3): 419-432. doi: 10.1080/13664539800200062.

Quicke, J. 1988. “The 'New Right' and Education”. British Journal of Education Studies. 36(1): 5-20. doi: 10.1080/00071005.1988.9973770.

Sachs, J. 2001. "Teacher professional identity: competing discourses, competing outcomes". Journal of Education Policy. 16(2): 149-161. doi: 10.1080/02680930116819.

Salter, B. and Tapper, E.R. 1988. "The Politics of Reversing the Ratchet in Secondary Education 1969-1986”. Journal of Educational Administration. 20(2): 57-70. doi: $10.1080 / 0022062880200206$.

Strain, M., and Simkins, T. 2008. "Continuity, Change and Educational Reform- Questioning the Legacy of the Education Reform Act 1988". Educational Management Administration and Leadership. 36(2): 155-163. doi: 10.1177/1741143207087770. 
Stronach, I., Corbin, B. McNamara, O. Stark, S. and Warne, T. 2002. "Towards an uncertain politics of professionalism: teacher and nurse identities in flux". Journal of Education Policy. 17(1): 109-138. doi: 10.1080/0268093011010008.

Webb, R., Vulliamy, G. Hamalainen, S., Sarja, A., Kimonen, E. and Nevalainen, R. 2004. “A comparative analysis of primary teacher professionalism in England and Finland".

Comparative Education. 40(1): 83-107. doi: 10.1080/0305006042000184890.

West, A., Sammons, P., Hailes, J. and Nuttall, D. 1994. "The Standard Assessment Tasks and the boycott at Key Stage 1: teachers' and headteachers' views in six inner-city schools". Research Papers in Education. 9(3): 321-337. doi: 10.1080/0267152940090304.

Whitty, G. 2008. “Twenty years of progress?” Educational Management Administration and Leadership. Journal of In-Service Education, 26(2): 281-295. doi:

$10.1177 / 1741143207087771$.

Wyse, D., and Torrance, H. 2009. "The Development and Consequences of National Curriculum Assessment for Primary Education in England". Educational Research. 51(1): 213-228. doi: 10.1080/00131880902891479. 